\title{
How often does conjugation in ciliates occur? Clues from a seven-year study on marine sandy shores
}

\author{
P. Lucchesi, G. Santangelo* \\ Dipartimento Etologia, Ecologia, Evoluzione, Via Volta 6, 56126 Pisa, Italy
}

\begin{abstract}
Conjugation is a distinctive process of ciliate sexual reproduction, and while its induction and progression have been widely investigated in lab-cultured strains of several species, little information has been gathered about the actual frequency of this sexual process in natural habitats. This study focuses on the frequency of conjugation in ciliates dwelling on Mediterranean sandy shores. Over the period 1990 to 1996, 680 sand samples $(1 \mathrm{ml})$ were collected along Italian coasts and examined just after collection for the presence of conjugating pairs. Overall, the samplings yielded 28890 individual ciliates belonging to 121 species, but only 20 conjugating pairs belonging to 8 different species. Conjugation, therefore, seems to be an erratic sexual phenomenon and not as frequent in ciliates of temperate marine sandy shores as previously thought.
\end{abstract}

KEY WORDS: Sexual reproduction · Conjugation · Population sexual structure · Protists · Ciliates · Sandy shores · Mediterranean Sea

\section{INTRODUCTION}

Sexual reproduction in ciliates, like in several plants and invertebrates, is a process apart from multiplication which is asexual. While the frequency of asexually multiplying cells in natural samples provides a clue for estimating protist population growth rates in the field (e.g. Reguera et al. 2003), few data are available on the actual frequency with which sexual reproduction occurs over the life cycle of ciliates in their habitats.

Sexual reproduction in ciliates follows 2 different pathways: conjugation and autogamy (Dini \& Nyberg 1993, Miyake 1996, Komori et al. 2002). Although both processes allow clones to renew their genome via micronuclear meiotic recombination, only conjugation leads to the exchange of genetic information via haploid micronuclei exchange between partner cells of complementary mating types.

Notwithstanding the paramount adaptive significance of conjugation and its putative relationships with genomic variability (Kusch \& Heckmann 1996), scant data on the actual frequency of this sexual process in nature have been gathered, and the significance of conjugation in structuring ciliate populations is still controversial (Kusch 1998).

Under laboratory conditions, after each conjugation ciliates go through a short 'immaturity period' after which they may once again conjugate with the sexually complementary strains (Dini \& Nyberg 1992). The possibility of easily inducing conjugation by favouring pre-conjugative interactions and synchronising complementary cells (e.g. Fujishima 1988, Luporini et al. 1992, Miyake 1996, Santangelo \& Bruno 2001) suggested that this process could also occur frequently in nature, though both the instability of the natural environment and the basically clonal population structure of protists (Kusch \& Heckmann 1996) could greatly reduce its frequency. As these studies were based on labcultured strains, they cannot provide any information about the actual incidence of conjugation in nature.

The high number of mating types found in several species, together with the high frequency of intraclonal selfing observed in old, crowded, lab-cultured strains, also suggested that conjugation may occur 
frequently in nature. It is difficult, however, to infer the frequency of conjugation in natural populations from such findings. Thus, the question of how frequently conjugation occurs in nature is still open.

As conjugating pairs remain united for several hours under laboratory conditions (Miyake 1996), they should also be easy to observe in freshly collected natural samples (i.e. before laboratory conditions could affect the onset of pairing in the samples). The frequency of conjugation in natural environments can thus be inferred by examining such fixed-volume samples. Unfortunately, no exhaustive data from such sampling are available in the literature.

Here we analyse the occurrence of conjugation in marine ciliate assemblages dwelling on Mediterranean sandy shores. During the period 1990 to 1996, a large number of sand samples were collected along Italian sandy shores and examined just after collection (Santangelo \& Lucchesi 1992, 1995, Lucchesi \& Santangelo 1997). In this framework, the occurrence of conjugating pairs was carefully recorded. These data are examined herein. We believe they can provide some insight into the actual frequency of conjugation within ciliate populations.

\section{MATERIALS AND METHODS}

Samplings were carried out between 1990 and 1996 in the Ligurian (Stns A, B, C, D, E) and Adriatic Seas (Stns F, G, H; Fig. 1).
Overall, 680 sand samples (1 ml) (434 during springsummer and 246 in autumn-winter) were collected at $40 \pm 10 \mathrm{~cm}$ depth during the morning low tide following methods and sampling designs described previously by Santangelo \& Lucchesi (1995). The occurrence of mating pairs in the sand samples could be affected by some periodicity of conjugation. According to Miyake \& Nobili (1974), conjugation occurs in Euplotes crassus lab-cultured strains with some periodicity, but the peaks of conjugation may be reached at any time of day. In addition, since rhythmicity of mating reactivity is well known in another ciliate (Barnett 1966), the duration of conjugation (10 to $36 \mathrm{~h}$ ) allowed us to also collect the pairs united during previous daily phases. Our samples may therefore be considered as random samples of different clones collected during different phases of their life cycle, which could also include conjugation. The frequency of conjugation, estimated on the basis of the length of the immaturity period in lab-cultured clones, could range between 12 and 42 conjugations $\mathrm{yr}^{-1}$ (Dini \& Nyberg 1992, Doerder et al. 1995).

Samples were transported to the laboratory in a thermal container and examined within $5 \mathrm{~h}$ of collection. Ciliates were extracted from the sand following Uhlig's ice-water method (Uhlig 1964) within 2 h of collection and examined as described below. Sand was filtered with a $250 \mathrm{~mm}$ mesh nylon net. The method was tested on pairs obtained by lab-cultured Euplotes crassus complementary strains for (1) effects of ice-water treatment on pairs of different ages, and (2) extraction effi-

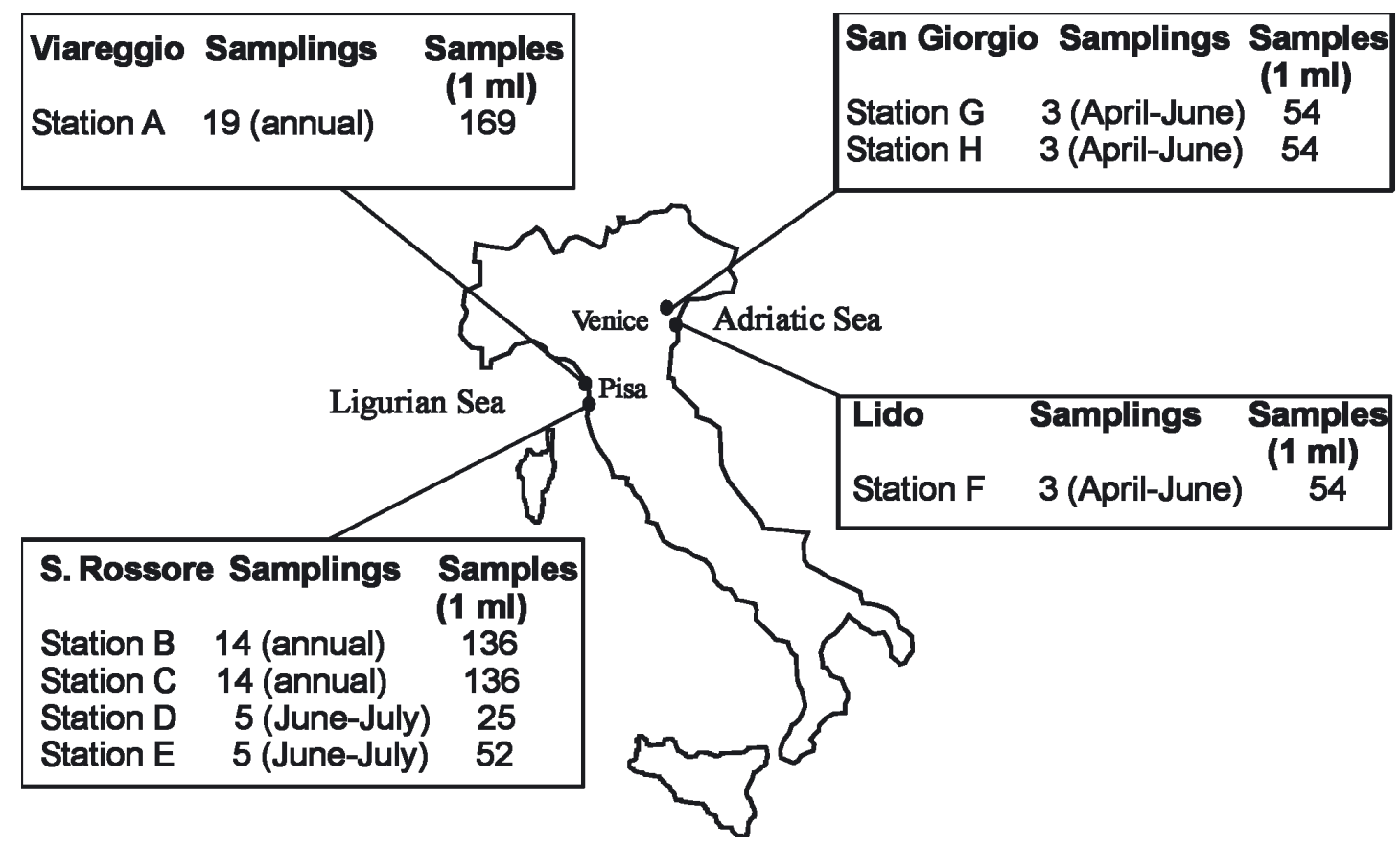

Fig. 1. Geographic distribution of the 680 sand samples $(1 \mathrm{ml})$ examined in this study 
ciency from $1 \mathrm{ml}$ sand samples on stable (those in 'holdfast union') pairs. Only pairs in early conjugation phase (within $2 \mathrm{~h}$ of conjugation) were split by the icewater treatment. As samples were processed $2 \mathrm{~h}$ after collection, the split pairs were mostly those formed after sample collection. Holdfast union pairs of ciliates are so permanently and tightly united (Fig. 2 B,C) that they can be split only by firmly pressing a thin glass needle on the cell-union region (Santangelo \& Nobili 1981).

The efficiency of the extraction of Euplotes crassus pairs in holdfast union was similar to that found for single ciliates $(90 \%)$. The method therefore could underestimate pair frequency by about $10 \%$.

The ciliate assemblages examined dwell in mediumto fine-sized grain, on poorly sorted sandy shores, variously exposed to hydrodynamic disturbance (Lucchesi \& Santangelo 1997). The temperature values were typical of shallow Mediterranean waters, characterized by a warm period (June to October), during which they range from 21 to $25^{\circ} \mathrm{C}$, and a cold period (November to May), in which they fall to a minimum $9.9^{\circ} \mathrm{C}$ (December). Salinity varies between 25 and 36 psu and oxygen between 8 and $50 \%$ atmosphere saturation.

Stn A was located at 'Marina di Levante', Viareggio $\left(43^{\circ} 51^{\prime} \mathrm{N}, 10^{\circ} 15^{\prime} 05^{\prime \prime} \mathrm{E}\right)$, an exposed sandy shore about $10 \mathrm{~m}$ from the coast. A total of 169 samples $(1 \mathrm{ml})$ were examined on 19 different occasions over 2 yr (1990 to 1991).

Stns B and C were located at the 'Gombo' area in the 'S. Rossore' Natural Park, Pisa $\left(43^{\circ} 43^{\prime} 06^{\prime \prime} \mathrm{N}\right.$, $\left.10^{\circ} 16^{\prime} 06^{\prime \prime} \mathrm{E}\right)$. Stn B was located on a shore sheltered by an artificial cliff, while Stn C was more exposed to hydrodynamic disturbance. A total of 272 samples
(1 ml) were collected from these stations on 14 different occasions over 2 yr (1993 to 1994).

Stn D was located near the coastline at the 'Fiume Morto' river mouth in the 'S. Rossore' Natural Park, while Stn E was located in the river mouth. During June and July 1992, 25 and 52 samples (1 ml) were collected on 5 different occasions at Stns D and E, respectively.

Stns $\mathrm{F}, \mathrm{G}$ and $\mathrm{H}$ were located near Venice $\left(42^{\circ} 25^{\prime} \mathrm{N}\right.$, $\left.12^{\circ} 21^{\prime} \mathrm{E}\right)$. Stn F was situated in the Adriatic Sea at 'Lido' Islet, a few meters from the coastline, while Stns $\mathrm{G}$ and $\mathrm{H}$ were located in the Venice Lagoon (S. Giorgio Islet). Overall, 162 samples (1 ml) were collected on 3 different occasions in April, May and June 1996.

\section{RESULTS}

The ciliate assemblages studied showed a clear-cut seasonal pattern: in spring-summer, ciliate density, patchiness and diversity were significantly higher than in autumn-winter (Santangelo \& Lucchesi 1995, Santangelo et al. 2000).

Pairs were found only in the spring-summer samples. Only 5 stations out of the 8 examined and only 11 out of 434 samples $(1 \mathrm{ml})(0.07 \%)$ yielded pairs (Table 1$)$.

Overall, out of 28890 ciliates (42.5 ciliates $\mathrm{ml}^{-1}$ ) belonging to 121 species and 39 genera, only 20 mating pairs $(0.07 \%$ of overall ciliates) of 8 species $(6.6 \%$ of species; Fig. 2A) were found in conjugation. Mating pairs had an average density of 0.029 pairs $\mathrm{ml}^{-1}$. Aspidisca sp. was found in conjugation in 4 samples (2 with 1 pair and 2 with 2 and 3 pairs), and Euplotes crassus in only 1 sample ( 7 pairs in the same sample).

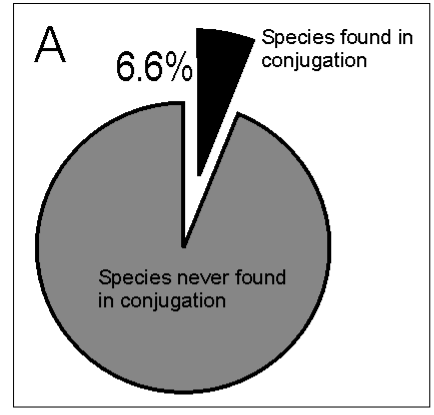

Fig. 2. (A) Percentage of species found in conjugation within this research, (B) an in vivo conjugating pair of Trachelocerca sp. (Karyorelictida) in holdfast union, and $(C)$ anterior region (scale bar $=40 \mu \mathrm{m})$. Differential interference contrast

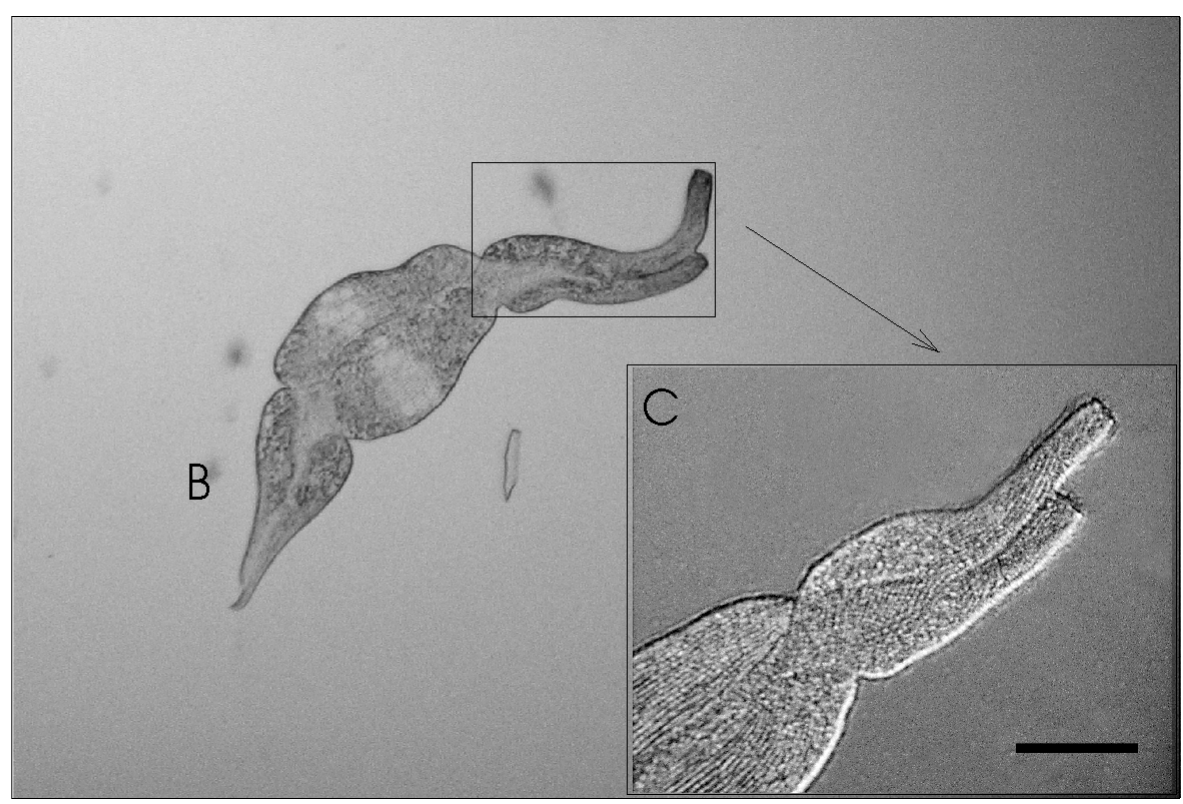


Table 1. Ciliate pair content in 434 sand samples collected in spring-summer. Pairs were found in 11 samples, in 9 of which the conjugating species reached a density $\geq 10$ cells ml${ }^{-1}$ (Column 5). The ratio between the density of the mating species and that of overall ciliates in the sample is shown (Column 6). In Columns 7 and 8, the overall ciliate density in the sample and that at the station are reported

\begin{tabular}{|c|c|c|c|c|c|c|c|}
\hline Stn & $\begin{array}{l}\text { No. } \\
\text { of } \\
\text { pairs }\end{array}$ & Pairs $\mathrm{ml}^{-1}$ & $\begin{array}{l}\text { Species found } \\
\text { in conjugation }\end{array}$ & $\begin{array}{c}\text { Mating } \\
\text { species } \\
\text { density } \\
\left(\text { cells ml } \mathrm{ml}^{-1}\right)\end{array}$ & $\begin{array}{c}\text { Mating } \\
\text { species/ } \\
\text { overall } \\
\text { ciliates (\%) }\end{array}$ & $\begin{array}{c}\text { Overall } \\
\text { ciliate density } \\
\text { in the sample } \\
\left(\text { cells } \mathrm{ml}^{-1}\right)\end{array}$ & $\begin{array}{c}\text { Overall ciliate } \\
\text { density }( \pm \mathrm{SD}) \\
\text { at the station } \\
\left(\text { cells } \mathrm{ml}^{-1}\right)\end{array}$ \\
\hline A & $\begin{array}{l}2 \\
1\end{array}$ & 0.012 & $\begin{array}{l}\text { Aspidisca sp. } \\
\text { Trachelocerca sp. }\end{array}$ & $\begin{array}{r}30 \\
6\end{array}$ & $\begin{array}{c}15 \\
3\end{array}$ & $\begin{array}{l}200 \\
198\end{array}$ & $113 \pm 96$ \\
\hline B & $\begin{array}{l}3 \\
7 \\
1 \\
1 \\
1\end{array}$ & 0.08 & $\begin{array}{l}\text { Aspidisca sp. } \\
\text { Euplotes crassus } \\
\text { Pleuronema marinum } \\
\text { Remanella obtusa } \\
\text { Tracheloraphys totevi }\end{array}$ & $\begin{array}{l}14 \\
20 \\
23 \\
10 \\
13\end{array}$ & $\begin{array}{c}30.4 \\
42.5 \\
50 \\
20 \\
25\end{array}$ & $\begin{array}{l}46 \\
47 \\
46 \\
50 \\
42\end{array}$ & $18 \pm 27$ \\
\hline $\mathrm{C}$ & No pair & & & & & & $9 \pm 13$ \\
\hline $\mathrm{D}$ & No pair & & & & & & $67 \pm 45$ \\
\hline E & 1 & 0.02 & Aspidisca sp. & 199 & 95.2 & 209 & $70 \pm 173$ \\
\hline $\mathrm{F}$ & $\begin{array}{l}1 \\
1\end{array}$ & 0.037 & $\begin{array}{l}\text { Aspidisca sp. } \\
\text { Loxophillum sp. }\end{array}$ & $\begin{array}{r}13 \\
4\end{array}$ & $\begin{array}{c}27 \\
8\end{array}$ & $\begin{array}{l}48 \\
50\end{array}$ & $12 \pm 20$ \\
\hline G & No pair & & & & & & $1 \pm 3$ \\
\hline $\mathrm{H}$ & 1 & 0.018 & Remanella sp. & 10 & 47.6 & 21 & $1 \pm 3$ \\
\hline Total & & 20 & & & & & \\
\hline
\end{tabular}

Mating pairs of each of the other species (Remanella obtusa, Remanella sp., Pleuronema marinum, Trachelocerca sp., Thracheloraphis totevi and Loxophyllum sp.) were found only once, with 1 sole pair in the sample (Table 1). In 9 out of 11 cases, the mating species showing a density between 10 and 199 cells ml ${ }^{-1}$ codominated or dominated the sample (15 to $95 \%$ of the overall ciliates, Table 1).

Pairs were always found in samples that showed a high density of ciliates, when compared to the densities found in other samples collected at that station (Table 1, Columns 7 and 8).

The data subdivided by station are briefly reported in the following:

Stn A. In these samples, $113 \pm 96$ and $9 \pm 8$ ciliates $\mathrm{ml}^{-1}$ (in spring-summer and autumn-winter), belonging to 58 species were found. The Shannon-Weaver index $(H)$ reached 2.08. Coleps hirtus, Pleuronema marinum and Remanella sp. co-dominated ( $60 \%$ of the overall ciliates). Only 2 species $(3.4 \%)$ were found to be mating: Aspidisca sp. (2 pairs) and Trachelocerca sp. (1 pair) (Table 1) equal to 0.012 pairs $\mathrm{ml}^{-1}$. Their density was 30 and 6 ciliates $\mathrm{ml}^{-1}$, respectively (15 and $3 \%$ of the overall ciliates).

Stn B. In these samples, $18 \pm 27$ ciliates $\mathrm{ml}^{-1}$ (springsummer) and $3 \pm 2$ ciliates $\mathrm{ml}^{-1}$ (autumn-winter) belonging to 40 species were found. The low equitability kept down diversity $(H=1.05)$, due to the clear-cut dominance of Pleuronema marinum and Coleps hirtus. Five species $(12.5 \%)$ were found mating: Euplotes crassus (7 pairs in 1 sample), Aspidisca sp., Pleuronema marinum, Remanella obtusa, Tracheloraphis totevi (1 pair each). Density was 0.08 pairs $\mathrm{ml}^{-1}$. The mating species reached $14,20,23,10$ and 13 cells ml ${ }^{-1}$ and accounted for $30,42,50,20$ and $25 \%$, respectively, of the overall ciliates.

Stn C. Overall, these samples yielded a low density: $9 \pm 13$ ciliates $\mathrm{ml}^{-1}$ (spring-summer) and $2 \pm 2$ ciliates $\mathrm{ml}^{-1}$ (autumn-winter) belonging to 33 species $(H=1.4$ ). Coleps hirtus and Pleuronema marinum were the dominant taxa. No mating pair was ever observed.

Stn D. These samples, which yielded $67 \pm 45$ ciliates $\mathrm{ml}^{-1}$, exhibited a clear-cut dominance of Pleuronema marinum and Coleps hirtus (Table 1). Overall, 28 species were found. The low equitability kept down diversity $(H=0.6)$. No mating pair was ever observed.

Stn E. Although ciliates reached a density lower than at Stn $\mathrm{A}\left(70 \pm 173\right.$ ciliates $\left.\mathrm{ml}^{-1}\right)$, in 1 sampling (in June) they reached the highest density we ever encountered (1206 ciliates $\mathrm{ml}^{-1}$ ). In spite of the highest species richness (43 species), diversity was low $(H=0.9)$, as it was heavily influenced by Aspidisca sp. dominance (44\% of the overall ciliates). Only 1 pair of Aspidisca sp. was found $\left(0.02\right.$ pairs $\left.\mathrm{ml}^{-1}\right)$ in a sample in which this species reached a density of 199 ciliates $\mathrm{ml}^{-1}$ (95\% of overall ciliates).

Stn F. Density increases from $1 \pm 1$ in early April up to $34 \pm 13$ cells ml $^{-1}$ in June. Thirty-five species were found and, due to a good equitability, diversity reached the highest value $(H=2.3)$. Pleuronema sp. 
dominated these samples. One pair of Aspidisca sp. and 1 of Loxophillum sp. were found (0.037 pairs $\mathrm{ml}^{-1}$ ). In these samples, the density of Aspidisca sp. and Loxophillum sp. was 13 and 4 cells ml ${ }^{-1}$, respectively $(27$ and $8 \%$ of the overall ciliates, respectively).

Stn G. These samples always yielded a low density $\left(1 \pm 1\right.$ ciliates $\left.\mathrm{ml}^{-1}\right)$. Overall, 17 species were found, the equitability was high and thus diversity reached a high value $(H=1.8)$. Aspidisca sp. dominated the species assemblage. No mating pair was ever observed.

Stn H. These samples also yielded a low density $(1 \pm$ 2 ciliates $\mathrm{ml}^{-1}$ ). Overall, 21 species were found, with Aspidisca sp. dominating the species assemblage. Due to the high species richness, diversity was high $(H=$ 1.8). Only 1 pair of Remanella sp. was found (0.018 pairs $\mathrm{ml}^{-1}$ ) in a sample in which this species dominated (10 ciliates $\mathrm{ml}^{-1}, 47.6 \%$ of overall ciliates).

\section{DISCUSSION}

Conjugation is generally considered to be the major sexual event in the life cycle of ciliates. During this process, sexually complementary cells mutually activate to acquire the ability to unite and form stable, mating pairs. In such pairs, a series of cellular and nuclear changes lead, via meiotic division, to migration, exchange and fusion of pronuclei (Miyake 1996). By increasing genetic variability, conjugation reinforces the vitality of clones and their fitness, and thus represents a powerful factor in evolution (Dini \& Nyberg 1993). Conjugation frequency is the main factor determining the genetic structure of ciliate populations but there is limited knowledge about its incidence in nature (Doerder et al. 1995).

We examined a large number of samples collected in different seasons over several years from Italian sandy shores, focussing on the occurrence of mating pairs; we believe such analysis provides valid information about the actual occurrence of conjugation in nature. Due to a $90 \%$ extraction efficiency (checked on cultured ciliates), the extraction method could account for an underestimation of pair frequency of $10 \%$.

The duration of immaturity has been described in few species; on these bases a cultured clone could conjugate 12 to 42 times $\mathrm{yr}^{-1}$ (Dini \& Nyberg 1992, Doerder et al. 1995). Out of 28980 ciliates and 121 species found (and a higher, undetermined number of clones), only a minimal percentage $(0.07$ and $6.6 \%$, respectively) was encountered in conjugation. We can thus conclude that the frequency of pairs was much lower than expected. Obviously our findings cannot exclude that some ciliates living in calm, fresh-water ponds could conjugate more frequently than those in marine, exposed sandy shores. Doerder et al. (1995) indicate a high frequency of conjugation in Tetrahymena thermophyla, based on immaturity of freshly collected clones; indirect, a posteriori, evidence of conjugation. In contrast, Nanney \& McCoy (1976) indicated, within natural populations of the Tetrahymena pyriformis complex, the existence of large numbers of asexual strains, which can constitute 30 to $50 \%$ of the overall strains collected in nature.

Mating was more frequent within patches of ciliates where the mating species attains a relatively high density and, in several cases, dominates the patch. Such conditions were common in spring-summer, the period during which all the pairs were found. Several interstitial protists tend to congregate at food sources, forming ephemeral multispecific patches (Fenchel \& Blackburn 1999, Santangelo et al. 2000, Smirnov \& Thar 2003). Such patches are more frequent in sheltered sandy shores (Lucchesi \& Santangelo 1997). Under laboratory conditions, conjugation occurs in ciliates that have been moderately starved, at the end of their exponential growth phase. Thus, it seems reasonable to suppose that ciliates mate under similar conditions in the field as well: when and were crowding occurs, ciliates may consume the food patch quickly and then conjugate. A high density of sexually complementary conspecifics greatly increases the probability of mating, by increasing both the frequency of encounters between sexually complementary partners and the intensity of pre-conjugative interactions (Luporini et al. 1992, Doerder et al. 1996, Miyake 1996). Such interactions may thus be more effective in crowded patches of conspecifics.

Conjugation frequency is an important component of the reproductive strategies of ciliates. It can be considered the result of complex interactions between growth rates, pre-conjugative interactions, distribution patterns and breeding systems of the different species (Landis 1986, Iwasa \& Sasaki 1987, Dini \& Nyberg 1993). Generally, ciliates with multiple breeding systems and highly sex-structured populations are considered to have more opportunities to conjugate than those with binary breeding systems, but the ciliate most frequently found in conjugation in our samples (the hypotrich Aspidisca sp.) exhibits a reproductive strategy characterised by a binary breeding system (Dini et al. 1987). It seems reasonable to suppose that the high density reached by Aspidisca sp. could have determined the relatively high frequency of its pairs in our samples. Our data therefore do not corroborate the hypothesis that conjugation occurs more frequently in multiple-breeding-system species.

In conclusion, our findings indicate that the frequency of mating among ciliates in marine temperate sandy shores is quite low: only a small percentage of 
species and a minimal percentage of ciliates were collected during their mating phase. Mating is more frequent within patches where the mating species attains a relatively high density. Finally, our results suggest that conjugation is an erratic sexual phenomenon (Fleckleton 2002), not as frequent in ciliate populations as previously believed.

Acknowledgements. We wish to thank F. Dini for useful suggestions on the manuscript, F. Frontini for providing Euplotes crassus complementary strains and A. Cafazzo for his revision of the English. This research was supported by the Italian Education Ministry (MURST), 40\% Project.

\section{LITERATURE CITED}

Barnett A (1966) A circadian rhythm of mating type reversals in Paramecium multimicronucleatum, syngen 2, and its genetic control. J Cell Physiol 67:239-270

Dini F, Nyberg D (1992) Development of sexual maturity in the ciliate Euplotes crassus: source of variation in the timing of maturity. Dev Gen 13:41-46

Dini F, Nyberg D (1993) Sex in ciliates. In: Jones JG (ed) Advances in microbial ecology. Plenum Press, New York, p 85-153

Dini F, Bracchi P, Giannì A (1987) Mating types in Aspidisca sp. (Ciliophora, Hypotrichida): a cluster of cryptic species. J Protozool 34:236-243

Doerder FP, Gates MA, Eberhardt FP, Muhittin A (1995) High frequency of sex and equal frequencies of mating types in natural populations of the ciliate Tetrahymena thermophila. Proc Natl Acad Sci 92:8715-8718

Doerder FP, Arslanyolu M, Saad J, Kaczmarek M, Mendoza M, Mita B (1996) Ecological genetics of Tetrahymena termophyla: mating types, i-antigenes, multiple alleles and epistasis. J Eukaryot Microbiol 43:95-100

Fenchel T, Blackburn N (1999) Motile chemosensory behaviour of phagotrophic protists: mechanisms for and efficiency in congregating at food patches. Protist 150:325-336

Fleckleton RP (2002) Chaotic mating systems. Trends Ecol Evol 17:493-495

Fujishima M (1988) Conjugation. In: Görtz HD (ed) Paramecium. Springer-Verlag, Berlin, p 70-82

Iwasa Y, Sasaki A (1987) Evolution of the number of sexes. Evolution 4(1987):49-63

Komori R, Harumoto T, Fujisawa H, Takagi Y (2002) Variability of autogamy-maturation pattern in genetically identical populations of Paramecium tetraurelia. Zool Sci 19: 1245-1249

Kusch J (1998) Local and temporal distribution of different

Editorial responsibility: John Dolan,

Villefranche-sur-Mer, France genotypes of pond-dwelling Stentor coeruleus. Protist 149: $147-154$

Kusch J, Heckmann K (1996) Population structure of Euplotes ciliates revealed by RAPD fingerprinting. Ecoscience 3: 378-384.

Landis WG (1986) The interplay among ecology, breeding systems and genetics in the Paramecium aurelia and Paramecium bursaria complexes. In: Corliss J, Parrerson DJ (eds) Progress in protozoology, Vol I. Biopress, Bristol, p 287-307

Lucchesi P, Santangelo G (1997) The interstitial ciliate micromommunity of a Mediterranean sandy shore under differing hydrodynamic disturbance. Ital J Zool 64:253-259

Luporini P, Miceli C, Ortenzi C, Vallesi A (1992) Development analysis of the cell recognition mechanism in the ciliate Euplotes raikovi. Dev Genet 13:9-15

Miyake A (1996) Fertilization and sexuality in ciliates. In: Hausmann K, Bradbury PC (eds) Ciliates, cells as organisms. Fisher-Verlag, Stuttgart, p 243-290

Miyake A, Nobili R(1974) Mating reaction and its daily rhythm in Euplotes crassus. J Protozool 21:584-587

Nanney DL, McCoy W (1976) Characterization of the species of the Tetrahymena pyriformis complex. Trans Am Microsc Soc 95:664-679

Reguera B, Garcés E, Pazos Y, Bravo I, Ramillo I, Gonzáles-Gil S (2003) Cell cycle and estimates of in situ division rates of dinoflagellates of the genus Dinophysis by a postmitotic index. Mar Ecol Prog Ser 249:117-131

Santangelo G, Bruno P (2001) An immunofluorescence technique for staining ciliated protozoans: highlighting cytoplasmic microtubular arrays and stages of micronuclear meiosis. Micron 31:207-210

Santangelo G, Lucchesi P (1992) The interstitial ciliates protozoa of a Mediterranean microcommunity. Hydrobiologia 230:79-92

Santangelo G, Lucchesi P (1995) Spatial distribution pattern of ciliated protozoa in a Mediterranean interstitial environment. Aquat Microb Ecol 9:47-54

Santangelo G, Nobili R (1981) Maintenance of mating reactivity and capacity of transferring meiotic induction by an activated to a homotipically united cell in Blepharisma. J Exp Zool 218:121-126

Santangelo G, Bongiorni L, Pignataro L (2000) Abundance of thraustochytrids and ciliated protozoans in a Mediterranean sandy shore determined by an improved, direct method. Aquat Microb Ecol 23:55-61

Smirnov V, Thar R (2003) Spatial distribution of amoebae in marine and freshwater bottom sediment. In: Cavallaro $G$, Luporini P (eds) Proc 4th European Congr Protistology. S. Benedetto del Tronto (Italy) September 2003. University of Camerino, Camerino

Uhlig G (1964) Eine einfache Methode zur Extraktion der valigen, mesopsammalen Mikrofauna. Helgol Wiss Meeresunters 11:178-185

Submitted: November 4, 2003; Accepted: May 14, 2004

Proofs received from author(s): June 29, 2004 